\title{
Lean Production in small and medium sized companies from the Free Economic Zone of Manaus: a reality or just fiction?
}

\section{Produção enxuta em pequenas e médias empresas da Zona Franca de Manaus: uma realidade ou apenas ficção?}

ISSN 0104-530X (Print) ISSN 1806-9649 (Online)

\author{
Francisco Waldilon Soares da Silva ${ }^{1}$ \\ Anabela Carvalho Alves ${ }^{1}$ \\ Manuel Carlos Barbosa Figueiredo ${ }^{1}$
}

\begin{abstract}
How to cite: Silva, F. W. S., Alves, A. C., \& Figueiredo, M. C. B. (2019). Lean Production in small and medium sized companies from the Free Economic Zone of Manaus: a reality or just fiction? Gestão \& Produção, 26(4), e4237. https://doi.org/10.1590/0104-530X-4237-19

Abstract: Given the current market demands, small and medium-sized enterprises (SMEs) are under pressure to change their working methods, implying changes in concepts and practices in order to improve their production systems and processes. Thus, the search for production methodologies, techniques and tools becomes urgent and imperative. One way to achieve this goal is to adopt the Lean Production (LP) methodology. This document presents the results of a survey, developed in the north of Brazil, involving 75 SMEs from the free economic zone of Manaus to assess the degree of LP implementation. The results showed a limited implementation of LP. Moreover, palliative practices (momentary relief), hopeful implementations and impediment factors are common. Attending to these results, the authors are tempted to say that LP is still a fiction for SMEs in this region.
\end{abstract}

Keywords: Lean production; SMEs; Survey; Free Economic Zone of Manaus.

Resumo: Dadas as atuais exigências do mercado, as pequenas e médias empresas (PMEs) estão sob pressão para mudar seus métodos de trabalho, implicando em mudanças de conceitos e práticas para melhorar seus sistemas e processos de produção. Assim, a busca por metodologias, técnicas e ferramentas de produção torna-se urgente e imperativa. Uma maneira de atingir esse objetivo é adotar a metodologia Lean Production (LP). Este documento apresenta os resultados de uma pesquisa para avaliar o grau de implementação do LP em PMEs do norte do Brasil, envolvendo 75 PMEs da zona econômica livre de Manaus. Os resultados mostraram uma implementação limitada do LP. Práticas paliativas (alivio momentâneo), implementações esperançosas e fatores de impedimento são comuns. Atendendo a esses resultados, os autores são tentados a dizer que o LP ainda é uma ficção para as PMEs dessa região.

Palavras-chave: Produção enxuta; PME; Pesquisa; Zona Franca de Manaus.

\section{Introduction}

The globalization of markets, technological advancement and the socio-economic situation of the countries are factors that impose a new order in the production of goods and services industry. In today's market just survive productive and competitive companies. Consequently, organizations are under pressure to change their ways, resulting in changes in concepts and methods to improve their production processes. Therefore, the search for production tools and techniques that allow for these purposes is a priority.
There are many techniques and tools of production proposed to ensure these goals. These are implemented and, consequently, the gains are presented in television documentaries, scientific journals, journal articles, websites and blogs, that disclose positive gains. But most of these results are related to the implementation of these techniques and tools in large companies (Bozdogan et al., 2000; Murman et al., 2002; Moeuf et al., 2016). This shows that this type of organization is at a more advanced stage

\footnotetext{
${ }^{1}$ Universidade do Minho - MINHO, Azurém Campus, CEP 4800-058, Guimarães, Portugal, e-mail: fwssilva@gmail.com; anabela@dps.uminho.pt; mcf@dps.uminho.pt
}

Received Aug. 15, 2017 - Accepted May 29, 2018

Financial support: None 
of implementation. In relation to small businesses, when quoted, information is scarce, preventing an overview of earnings (Van Goubergen et al., 2003; Pingyu \& Yu, 2010; Bakås et al., 2011; Buehlmann \& Fricke, 2016).

Small companies, also known as small and medium-sized enterprises (SMEs), assume crucial importance in the world economy. They represent $95 \%$ of all companies and are responsible for approximately $50 \%$ of the gross domestic Product (GDP) of their respective countries. In addition, these represent 60 to $70 \%$ of the total existing jobs (European Commission, 2008; OIT, 2015).

In Latin America and Caribbean, SMEs generate $47 \%$ of jobs in the region and, if coupled with the self-employed workers, this percentage reaches $75 \%$ (OIT, 2015). But due to new demands of the market, the SMEs began to face new challenges, a more aggressive competition and increasing requirements of the type "want the best, paying less". To act and keep in the new market environment has become imperative for SMEs set up new processes of structuring, both external way, in the case of the relationship with customers and suppliers, as internally, with regard to its management practices, especially with respect to production processes that are one of the main factors that make up the cost of products. According to Bakås et al. (2011) a way to achieve these goals is through the adoption of the practices and techniques of LP.

LP was the name given to the Toyota Production System (Ohno, 1988) and released by Womack et al. (1990a) a production methodology that uses techniques and tools able to root out all the unnecessary activities (waste) in the production of goods and services, making people and the production processes more efficient and effective, reducing costs and generating value to the final consumer (Jones \& Womack, 2004).

However, little is known about the maturity and context of implementation of LP in SMEs (Saurin \& Ferreira, 2008; Pingyu \& Yu, 2010; Bakås et al., 2011; Buehlmann \& Fricke, 2016). This may be due to several causes such as implementations made through consultancies that do not allow to see the results and does not generate studies for the academy and the presence of obstacles to implementation (employee resistance to innovation, level of knowledge of relatively low staff, etc.), implementations of the LP in large companies, making it almost impossible to obtain information about the gains (Bakås et al., 2011) end the assumption that the non-implementation of the LP in SMEs is due to the fact that the specific particularities of SMEs were not sufficiently adequate (Moeuf et al., 2016).

In this way, considering the necessity of knowledge about the implementation of LP in SMEs, researchers responsible for this work developed an exploratory research based on a questionnaire to raise information, having as target public companies of this size (businesses) of the Manaus Free Zone (ZFM). This paper presents the results of this work showing that companies studied implemented an LP approach fragmented in some of their practices.

The ZFM is an economic development model implemented by the Brazilian Government with the purpose to achieve an economic source in the Western Amazon (SUFRAMA, 2016). It is formed by Occidental Amazon States: Acre, Amazonas, Rondônia and Roraima and the towns of Macapá and Santana, Amapá. Covers three economic poles (commercial, industrial and agricultural) that are subdivided into 18 economic subsectors with approximately 600 high-tech industries generating more than half a million jobs, direct and indirect, mainly in the sectors of electronics, two wheels and chemist. Among the products manufactured, are included: cell phones and video and audio, televisions, motorbikes, concentrates for soft drinks, among others. The agricultural pole houses projects the activities of food production, agro-industry, fish farming, tourism, wood processing, among other (SUFRAMA, 2016).

\section{Literature review}

LP concept emerged in Japan after World War II. Its source was the Toyota Production System (Ohno, 1988), developed by Toyota Motor Company contributing to greater prominence of Toyota in the Japanese market (Monden, 1993). Over the years, went on to confront the concept, dominant at that time, the mass production system arousing the attention of many researchers, mostly North Americans. In 1988, the term Lean Production System engine is first used by John Krafcik (1988), member of the IMVP - International Vehicle Program study group, and getting greater repercussions in 1990 through the book entitled "The machine that changed the world" by researchers James P. Womack, Daniel T. Jones, and Daniel Roos (Womack et al., 1990b), where they mention that the implementation of LP through the continuous improvement of processes can reduce resource consumption by half (doing more with less), instead of creating rules and bureaucracy, and also enabling people to continuously improve their activities, whether they are internal or external (efficiency and effectiveness). To implement LP, these authors propose a following five steps cycle (Womack \& Jones, 1996):

1. Value- analysis and identification of what is recognized as customer or consumer value;

2. Value Stream - identification of processes that are required to create value; 
3. Flow - making process flows routines for employees;

4. Pull production - start the production or service only against customers' requests;

5. Pursuit perfection - continuously improve what is required and always seeking perfection.

These steps when applied with the support of the leadership of the organization, ensure a higher performance and leads to elimination of unnecessary production activities or services (defects, excess production or overproduction, waiting, transportation, handling, processing, stock, etc.). Consequently the objectives are reached and the success will come naturally (Womack \& Jones, 1997; Liker \& Meier, 2007).

Although LP had its origins in production, currently, its implementation was extended to many areas including to education (Alves et al., 2014). At the same time, the scientific community has been aware of this success and the number of publications is high, as seen in reviews of literature on Lean (Stone, 2012; Arlbjørn \& Freytag, 2013; Bhamu \& Sangwan, 2014; Jasti \& Kodali, 2014).

Despite this success, barriers to implementation of LP are still many (Jadhav et al., 2014). These barriers in SMEs are frequently (Pingyu \& Yu, 2010), related to factors such as leadership, involvement of management for decision making and attitude of employees, lack of resources and knowledge, and organizational culture (Achanga et al., 2006; Bakås et al., 2011). However, there may be forces and weaknesses associated with the fact that they are SMEs, since some of these factors are under the responsibility of the same person (Moeuf et al., 2016).

It is important to realize that the national context of SMEs can impact the implementation of LP. For example, according to the study of Panizzolo et al. (2012) on LP implementation in companies of India, the participation and empowerment of workers so necessary for a successful implementation can be difficult to achieve given that these new relationships are not simple to establish in the context of developing countries where workers are often treated unfairly.

Additionally, the implementation of LP in companies in the United Kingdom is supported by the Department of Trade and industry, in an initiative to promote increased productivity, known as Manufacturing Advisory Service (MAS) in SMEs (Achanga et al., 2006). Another study, from Brazil, showed that the companies studied even having used practices in a fragmented manner, LP implementation improved their operational performance (Godinho et al., 2016). Also, SMEs, independently, of the country or sector, seems eager to implement LP (Pingyu \& Yu, 2010; Dorota Rymaszewska, 2014; Hu et al., 2015; Maia et al., 2016; Antosz \& Stadnicka, 2017) even when they know that will face some challenges as the one described above as well others related with the necessary knowledge (Cowger, 2016).

\section{Context}

SMEs are classified according to the realities of each country's market. The European Union defines SMEs as those companies with less than 250 employees and they are divided into three categories, according to their size: a) micro-enterprises - are companies that have less than 10 employees; b) small businesses - among 10 and 49 employees; and c) SMEs enterprises ranging from 50 to 249 employees. In addition, the annual turnover may not exceed $€ 50$ million, or its annual balance exceeds $€ 43$ million (European Commission, 2008).

In the United States the US SBA - Small Business Administration (U.S. Agency for small businesses) sets the SMEs into two types: a) manufacturing companies and mining industries that keep up to 500 employees; and b) companies that do not manufacture and have average annual revenue of up to $\$ 6$ million. The average annual revenue is measured on the basis of the last three full fiscal years of the company (SBA, 2017).

In Brazil, SMEs are classified by the Statute on microenterprise and small business (Law No ${ }^{\circ}$. 9,841/99) and by Simple national (Differentiated, simplified and favored tax regime provided for in Complementary Law No. 123, dated 12.12.2006), using classification requirement, annual gross revenue (Table 1). Already the Brazilian service of support for micro and Small businesses - SEBRAE and the RAIS/MTE (Annual Social information / Ministry of labour and employment of the Federal Government) classification based on number of employees (SEBRAE, 2015).

Concerning economic importance, SMEs represent $29 \%$ of the country's PIB, consisting of 3,6 million of

Table 1. Classification of micro, small and medium enterprises by criterion of annual gross revenue and number of employees.

\begin{tabular}{lccc}
\hline & Micro Small & Enterprise & Medium Enterprise \\
\hline SME STATUS (annual gross revenues) & $\mathrm{R} \$ 244.000,00$ & $\mathrm{R} \$ 1.200 .000,00$ & -- \\
SIMPLE NATIONAL (annual gross revenues) & $\mathrm{R} \$ 120.000,00$ & $\mathrm{R} \$ 1.200 .000,00$ & -- \\
RAIS/MTE (number of employees) & $0-19$ & $20-99$ & $100-499$ \\
SEBRAE (Industry) & $0-19$ & $20-99$ & $100-499$ \\
SEBRAE (trade and services) & $0-09$ & $10-49$ & $50-99$ \\
\hline
\end{tabular}

Source: Adapted from SEBRAE (2015). 
formal enterprises (23\%) and 1 million (6\%) informal companies. They occupy $44 \%$ of the formal workforce and 12,9 million of entrepreneurs and workers of the informal sector in the country. SMEs mobilizing 60 million of the population directly occupied forming the main foundation of the structure of absorption of labor with great flexibility and democratization of opportunity (SEBRAE, 2014). In addition to these characteristics, the growth of these companies is around 9\% per annum (SEBRAE, 2015).

\section{Research methodology}

This paper aims to expose a perspective of LP implementation in SMEs in the free economic zone of Manaus. With this it is expected to find new ideas to provide a sustainable way of implementation in this class of company. To fulfill this objective, and to document the results, an exploratory study was carried out, which is indicated when there is little knowledge about the subject under study. All steps of the methodology are shown in Figure 1.

The study began with a review of LP and the importance of SMEs to the world economy, which were briefly discussed. This led to demonstrate the current gap and a real need to know the reality related to the implementation of LP in SMEs. The research developed is also intended to lead to the creation of new ways of implementing LP. For this, the authors used a questionnaire that was sent to the selected SMEs by e-mail. Telephone was also used to establish a first contact, Figure 1.

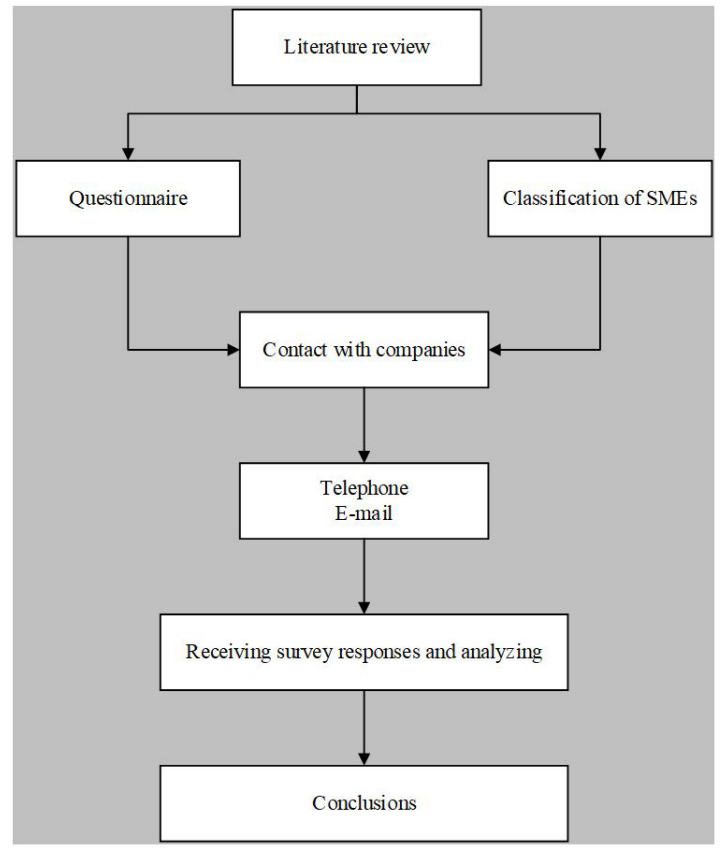

Figure 1. Research Methodology.

\subsection{Search sample}

The survey population consists of 150 SMEs that are based in the northern region of Brazil. These SMEs were identified in a study done by one of the researchers involved in this work. The study aimed to find out which and how many small businesses are active in the Manaus free trade zone (ZFM). The source of the data was the Superintendence of the Manaus Free Trade Zone - SUFRAMA. Using the data obtained it was possible to catalog 400 companies that are approximately divided into three economic poles (commercial, industrial and agricultural) of ZFM.

Among the 400 companies identified, a selection was made considering the criterion of number of employees (BNDES, 2015). This resulted in 150 SMEs that were selected for this research. Then, based on the core of expertise, these were subdividing in 18 economic subsectors. These subsectors are identified in Table 2, as well as the number of participating SMEs per subsector.

\subsection{Construction of the questionnaire}

The questionnaire was divided into six sections containing 45 questions addressed to the leaders of SMEs located in the ZFM:

Table 2. Economic subsectors of ZFM, quantity questionnaires sent, and response obtained.

\begin{tabular}{lcc}
\hline \multicolumn{1}{c}{ Economic subsector } & $\begin{array}{c}\mathbf{N}^{\mathbf{}} \\
\text { SME }\end{array}$ & Replies \\
\hline Non-alcoholic drinks and & 6 & $\mathbf{1}$ \\
concentrates. & & \\
Editorial and graphic. & 5 & $\mathbf{0}$ \\
Electrical, electronic and & 32 & $\mathbf{2 7}$ \\
communication. & & \\
Wood. & 11 & $\mathbf{5}$ \\
Mechanic. & 13 & $\mathbf{8}$ \\
Metallurgist. & 8 & $\mathbf{5}$ \\
Non-metallic minerals. & 7 & $\mathbf{5}$ \\
Furniture. & 22 & $\mathbf{1 8}$ \\
Paper, cardboard and pulp. & 9 & $\mathbf{5}$ \\
Rubber products. & 5 & $\mathbf{2}$ \\
Food products. & 5 & $\mathbf{0}$ \\
Chemist and pharmacist. & 4 & $\mathbf{1}$ \\
Products of plastics. & 5 & $\mathbf{0}$ \\
Textile. & 4 & $\mathbf{2}$ \\
Clothing, fabrics and travel articles. & 5 & $\mathbf{2}$ \\
Transport equipment & 4 & $\mathbf{0}$ \\
Construction. & 2 & $\mathbf{1}$ \\
Miscellaneous (optical Pole, & 3 & $\mathbf{0}$ \\
photographic equipment and & & \\
accessories, toys, others.), & & \\
Outcome & 150 & $\mathbf{8 2}$ \\
\hline
\end{tabular}


Section I - The details of the person responsible for the questionnaire - name, contact and position (03 questions);

Section II - General information about the company - company name, number of employees, age average of people working in production, products, market, size, volume of business and strategies adopted to face competition (11 questions);

Section III - Identification of the production model used by the Organization - it is presented to participants a range of production models seeking to know the models that more closely match the company practices. In addition, which are the measures adopted by companies to face competition and strategies to solve problems that arise and, finally, whether the current production model meets the needs of the company and the employees (04 questions);

Section IV - Knowledge about the production model LP - These questions seek to know the level of knowledge of the participants about the concept, its tools and which tools were implemented or may be considered for implementation (Liker, 2004) (8 questions);

Section V - Process of implementation of Lean Production - these questions are directed to companies that have already implemented the LP. The objective is to identify what were the reasons that led the company to implement Lean: How the implementation was performed and which methodology was used, training, importance, difficulties in implementation. Also, to determine if the implementation was restricted to one sector and finally to know the degree of difficulty for implementation (13 questions);
Section VI - Satisfaction with Lean production model - in this section, the last of the questionnaire, we seek to know the importance of having implemented LP, the degree of satisfaction, benefits obtained and finally the current understanding of the company with respect to the LP model (6 questions).

To make the questionnaire easy to understand for the respondents, over 45 questions, five procedures for responses were established:

1. Questions where answers are textual fields;

2. Questions where possible answers are "Yes"," No" or "Do not know";

3. Questions with predefined answers (possibilities), allowing multiple answers;

4. Questions involving a scale concerning the degree of difficulty;

5. Questions involving a satisfaction scale and its reasons.

Before starting the release and distribution of the questionnaire, it was presented to five employees to test questionnaire fill time (less than 8 minutes) and to validate the construction of sentences and its understanding (Google Drive, 2017).

\subsection{Process of dissemination and distribution of the questionnaire}

After validation, the questionnaire was released and distributed through e-mail during the period from 01 August to 30 September 2016 to 150 SMEs, divided into 18 economic subsectors in the ZFM (Table 2).

Before sending the questionnaire, contacts were made with all the selected companies to obtain

Table 3. Identification of the respondents of the research.

\begin{tabular}{|c|c|c|c|c|c|c|c|}
\hline \multirow[b]{2}{*}{$\begin{array}{l}\text { Economic } \\
\text { subsector }\end{array}$} & \multicolumn{7}{|c|}{ Respondents / Participants/ Valid Answers } \\
\hline & Director & $\begin{array}{c}\text { Materials } \\
\text { Analyst }\end{array}$ & Adm. & $\begin{array}{l}\text { Production } \\
\text { Engineer }\end{array}$ & $\begin{array}{l}\text { Production } \\
\text { Supervisor }\end{array}$ & $\begin{array}{c}\text { Operational } \\
\text { Manager }\end{array}$ & $\begin{array}{c}\text { Commercial } \\
\text { Manager }\end{array}$ \\
\hline $\begin{array}{l}\text { Electrical, } \\
\text { electronic. }\end{array}$ & 1 & 2 & 1 & 21 & 1 & & 1 \\
\hline Wood. & & & & 2 & 1 & 1 & \\
\hline Mechanic. & & 5 & & 3 & & & \\
\hline Metallurgist. & & & & 3 & 1 & 1 & \\
\hline $\begin{array}{l}\text { Non-metallic } \\
\text { minerals. }\end{array}$ & & 2 & & 3 & & & \\
\hline Furniture. & & & & 14 & 1 & 4 & \\
\hline Paper, others. & & & 2 & 2 & & & 1 \\
\hline Rubber products. & 1 & & & & 1 & & \\
\hline Outcome & 2 & 9 & 3 & 48 & 5 & 6 & 2 \\
\hline
\end{tabular}


the e-mail address for which the access link to the questionnaire should be sent. At this point, it was also disclosed the importance of research and their possible future contributions to SMEs. This action demonstrated the importance of a previous contact with the target population. It contributed for a greater interest by the audience and accelerated responses.

\subsection{Analysis of the data}

Taking into account the volume of information designed for the questionnaire, the importance of this article is the introduction of descriptive statistics and the realization of the analysis and interpretation of data quality supported by the literature.

\section{Results and discussion}

Given the population targeted, 150 SMEs, the number of responses obtained through the questionnaire was considered significant (Eiriz, 2001): 82 responses $(55 \%)$. After a validation assessment, this number was reduced to 75 responses considered valid (Table 3 ). The results obtained from the research are presented and discussed in the following sections.

\subsection{Identification of respondents}

The majority of the respondents has higher education and are professionals who occupy positions of leadership within their companies and demonstrated knowledge regarding the concept of LP (Table 3).

Production engineers represent the largest number of participants (64\%), demonstrating that they are present in several economic subsectors, particularly in the subsectors Electric, electronic and communication, wood, mechanics, metallurgy, nonmetallic minerals, furniture and paper in SMEs. In second place come professional analysts of materials $(12 \%)$. Professionals in other positions participated with smaller representations (24\%).

\subsection{Identification of companies}

The participating companies, $8 \%$ are multinational and $92 \%$ national, all based in the State of Amazonas, within the Manaus Free Zone (ZFM). From these, $70 \%$ operate in the local market (domestic), $4 \%$ in the international market and $26 \%$ present in the national and international market. The workforce in production is aged mainly in the range 20 to 60 years $(84 \%)$ and more than 60 years $(16 \%)$. Related with the annual turnover, $5 \%$ of the companies have an annual turnover up to USD 640 thousnad, 52\% between USD 640 thousnad to USD 4.2 million and $42 \%$ above USD 4.2 million up to USD 24 million (BNDES, 2015). Concerning economic activity sectors, $36 \%$ of these companies belong to the economic subsector of electrical, electronic and communication materials. In second position (25.3\%) is the real estate economic sub-sector. SMEs of six other subsectors $(38,7 \%)$ also participating have less representation. Concerning the number of employees (labor), all are in the range (09 to 499) to be considered SMEs (BNDES, 2015; SEBRAE, 2015).

According to the data displayed in this section, we can say that companies participating in the research are part of the industry that transforms raw material into either, a finished product, or an intermediate for other manufacturing industry, SMEs, national and multinational companies, and have already implemented somehow LP methods and tools (Figure 2).

\subsection{Measures adopted to face competition}

In times of high volatility in the markets, well-planned strategic measures are essential for a company, mainly small, to learn how to behave in a scenario of lower economic growth and international protectionism. For the interviewees, a list of measures was presented, which could give more than one answer. In this context, the research found three measures to face

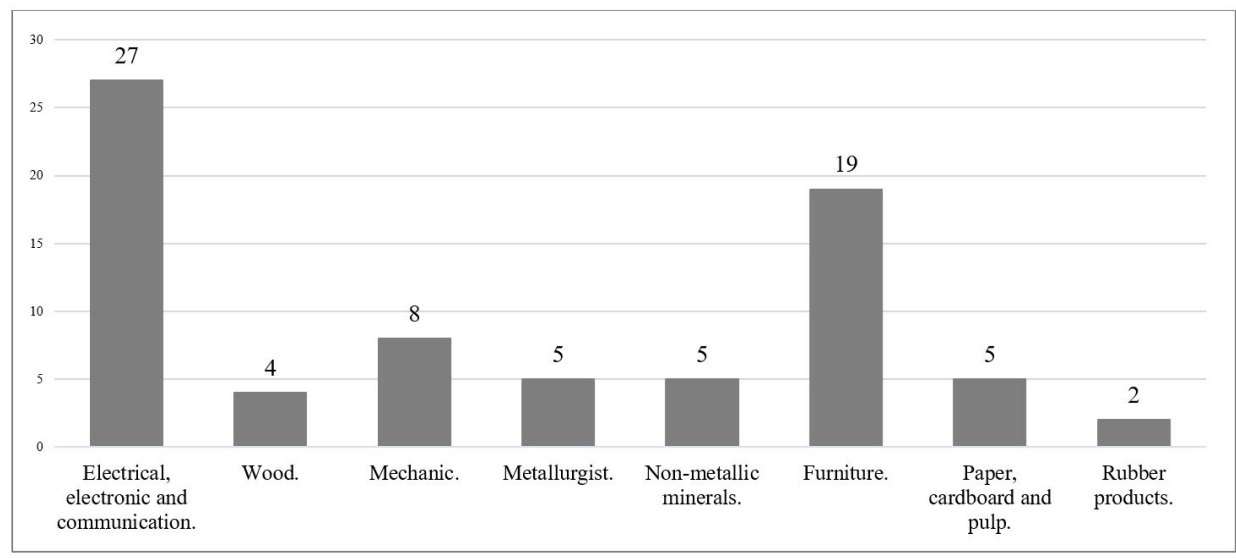

Figure 2. Economic subsectors and number of companies participating in the survey. 
the competition to be common practice for SMEs participants (Figure 3):

1. Practicing an efficient management (94.7\%);

2. To look for new niche markets $(49.3 \%)$; and

3. To reduce the cost of products $(33.3 \%)$.

In practice, these are measures that require quick and correct actions from enterprises to ensure implementation. To accomplish this, the search for techniques and tools to balance production between processes is imperative and the team members involved should be familiar with the types of production systems used (Moreira, 2012), otherwise, the final result may not be as expected.

\subsection{Production model and strategies to solve problems}

In an attempt to understand which, the production system is implemented in the participating SMEs, a list of 11 production models was presented. From the respondent companies, $50.7 \%$ considered Just-in-Time
(JIT) and 28\% LP the models that more closely match those used by them (Figure 4).

Among the respondents, $56.1 \%$ reported that they are satisfied with their current production model and $43.9 \%$ dissatisfied. However, $52 \%$ of these consider that LP can be a model to be implemented.

To tackle problems that may arise, four strategies stand out and are commonly adopted by SMEs companies:

1. Keep stock of finished products for customers who can ask for more ("Just-in-case") or new clients (72\%);

2. Keep stock of raw material (example: to cover for suppliers' failures) (6\%);

3. Produce more, because machines can fail (13\%); and

4. Produce more, because suppliers are not reliable (9\%).

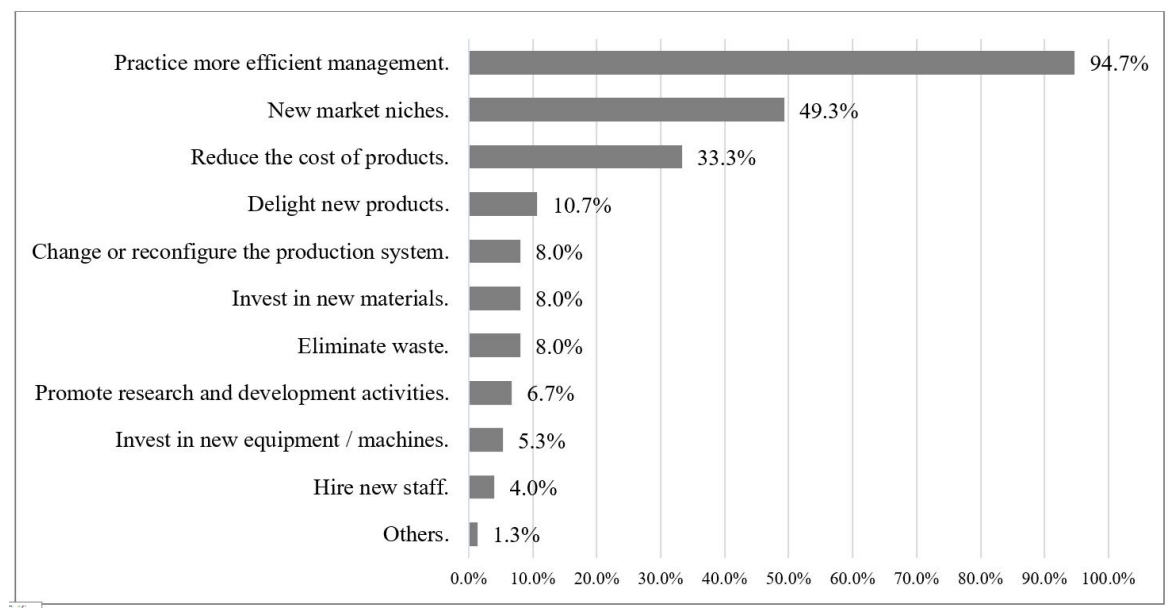

Figure 3. Measures adopted to face the competition.

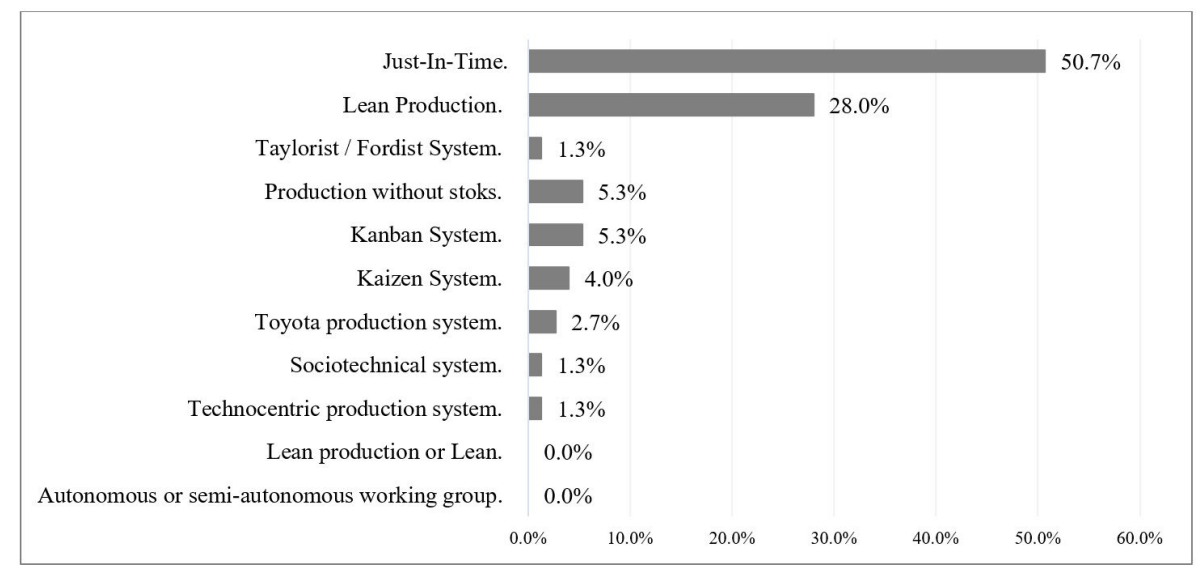

Figure 4. Production systems. 
Failures from suppliers, geographic and logistics problems in this region are factors that may explain the stock of raw materials. So, it's understandable the adoption of this type of strategy in participating organizations. Because in the region where they are based, the transport of materials has additional difficulties. Keeping finished stock, producing more, on the basis that machines may fail and that suppliers are not reliable, are strategies that can generate waste as: stock maintenance costs, unnecessary transport, unnecessary movement, loss and obsolescence of products.

The basis for a production without waste is to control the amount of material required for the production (Just-In-Time). This requires to understand deeply the needs for production and to be able of controlling variation, always seeking a production function well-balanced, without on heels, without bumps (Bodek, 2002). This kind of strategy adopted by SMEs assume palliative actions (momentary relief). This is contrary to LP, that is producing the right amount and only when requested by the client (Jones \& Womack, 2004).

\section{Understanding processes and implementation of Lean Production}

From the 75 SMEs studied, only 35 (47\%) reported having implemented LP. In the following sections, it is presented and discussed reasons, methods of implementation, training of employees, difficulties encountered and benefits earned with the implementation.

\subsection{Understanding of Lean methodology and tools}

Concerning the understanding of the LP and its tools, $91.4 \%$ of the participants believe that LP is a customer-focused model that seeks the elimination of unnecessary activities (waste) and the timely delivery of quality products and low cost, having support from a set of tools (Jones \& Womack, 2004). To determine whether the respondents are familiar with these tools, a list was presented. These tools can be seen in Figure 5.

With respect to the implementation of these tools (or practice), the most implemented was the $5 \mathrm{~S}$ with $98.6 \%$ of participants who noted that already have implemented, then the visual management $94.6 \%$, Kanban system $86.5 \%$ and $85.1 \%$ for production cells. This result is consistent with the aforementioned perception that most participants have knowledge of the subject. Concerning the low implementation rates of some tools, possibly it is linked to lack of knowledge of some of the respondents or lack of knowledge of the designation used here, for example, One-Piece Flow (OPF) or, at least, the preference for smaller lots, is usually, implemented when cells are implemented (Alves et al., 2015).

In respect to the LP tools listed in the survey (Figure 5), 4.4\% of the participants associate all of them to LP, $86.8 \%$ associate only some and $8.8 \%$ do not associate any with LP. However, among the

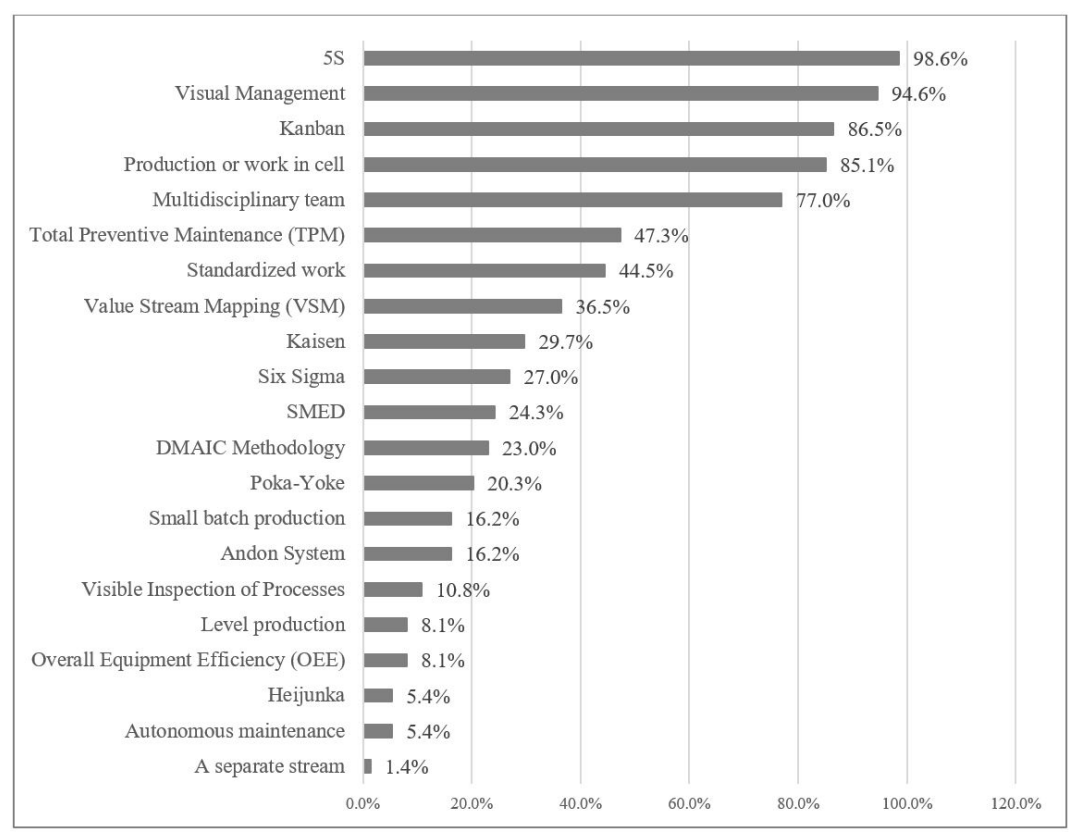

Figure 5. Knowledge of the Lean Tools. 
participants there is no consensus concerning the association of these tools to LP. This is understandable, since there is some discussion reported in the literature on how many and which ones are really Lean Tools (White et al., 1999).

According to the data presented, it can be said that respondents of the questionnaire are familiar with the subject LP, both in terms of theory and practice, which confirmed that the problems related to their business went unanswered in order to reflect the reality of them.

\subsection{Reasons to implement LP}

Among the range of reasons which may lead a company to implement LP, included in the questionnaire, three reasons presented higher prevalence:

1. Top management defined this implementation as a strategic objective to be achieved (48.6\%);

2. Other companies (for example, a client company) have implemented this model and this influenced decision-making (42.9\%);

3. The company was not satisfied with the previous model $(22.9 \%)$.

Current markets are imposing changes in companies that, in a way, are forced to change their production models or even to replace them, in addition to forcing a change in market perceptions. In other words, a deeper look to competition may contribute to change strategies more quickly. Therefore, it is natural that these reasons mentioned arise, giving a connotation of hope - conquer the same profits before obtained by other companies and also to get fast results to ensure productivity and competitiveness in the market.

In general, the results show that the initiative to implement LP is minimal with reference to the requirement of customers and of corporate policies.
This particularity is not negative, demonstrating interest in implementation. However, if LP is not implemented correctly and appropriately in this type of company, it can be an additional factor of apathy, mainly, if results do not come quickly.

\subsection{Methodology used for the implementation of LP and area of application}

Among the 35 SMEs companies that reported having implemented LP, only $97 \%$ reported how the process was implemented (Figure 6). Of these, 91.2\% chose to hire consulting firms, $5.9 \%$ teams composed of some employees and third parties (persons related to consulting companies) and $2.9 \%$ the experience of the employees.

Research conducted by Saurin et al. (2010) and Bakås et al. (2011) also presented equivalent results. With respect to the method used for implementation of LP, $65.7 \%$ of SMEs reported having adopted the methodology employed by the consulting firms. Concerning the scope of implementation of LP, 33\% of SMEs participants reported that extended it to the entire value chain, i.e., all suppliers, distributors and customers and for $67 \%$ implementation was restricted to the area of production (Figure 7).

\subsection{Training of employees}

Most of the training of employees (65.7\%) was held by the consulting firms, based on meetings covering topics such as: Lean concepts, Lean tools for relevant sectors.

In practice, data obtained with respect to training of employees contradicts the LP concepts. To ensure the necessary organizational change to synergy with LP principles, the company must ensure, at least in the LP project, medium- or long-term guidance and the availability of sufficient knowledge to establish

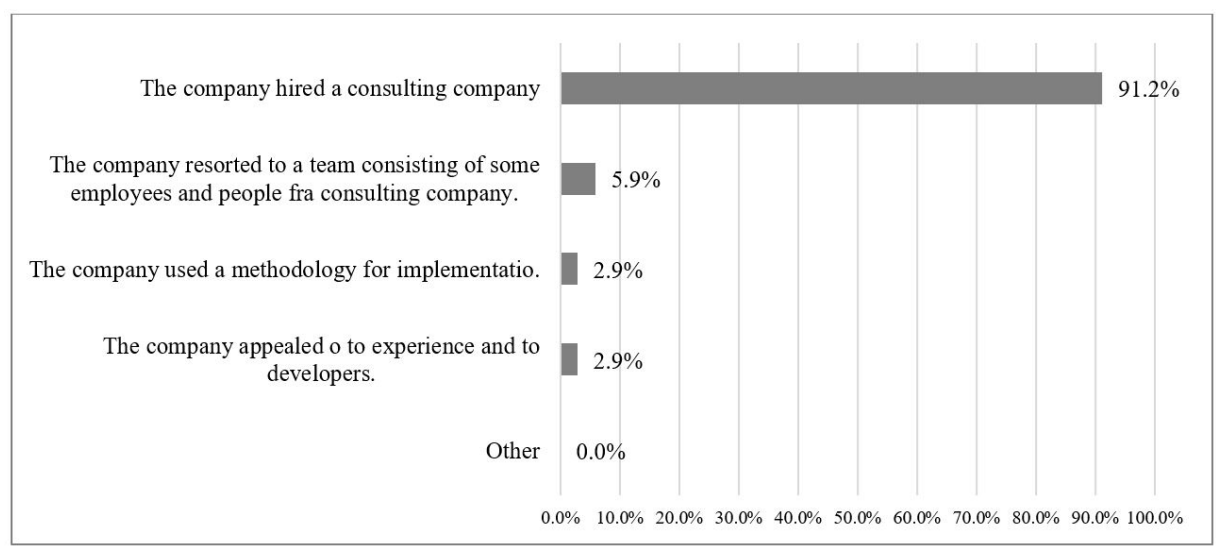

Figure 6. Process of LP implementation. 
and maintain LP practices and tools (Hines et al., 2004). The formation of teams able to understand leadership, expertise and decision-making is fundamental. LP success depends on a present and strong leadership, determining to their subordinates the steps to be followed in order to achieve the objective despite the difficulties that might arise.

\subsection{Difficulties to implement the LP}

There are many peculiarities of SMEs which enable success with LP (Smart et al., 2004), but there are also difficulties (Shah \& Ward, 2003; Papadopoulou \& Özbayrak, 2005; Marodin, et al., 2015). Achanga et al. (2006), as already mentioned, describe various difficulties in SMEs: size of the company, high costs with training and consultancies, financial limitations, lack of quality from suppliers and lack of technical capacity of leaders and employees. In fact, there are many difficulties presented in the literature that may appear as barriers to LP, referred in the literature review. The data obtained with respect to this question showed a predominance of three options provided in the questionnaire for participants (Figure 8):

1. Resistance attitudes of employees;

2. Difficulty in understanding some LP Tools; and

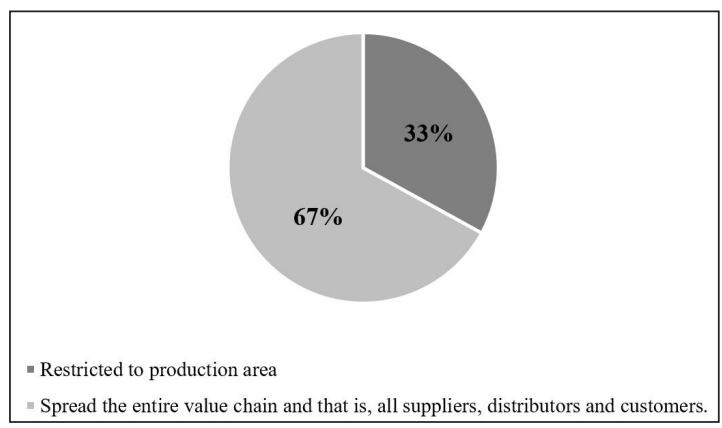

Figure 7. Areas of LP implementation.

\section{Lack of knowledge of LP principles.}

These difficulties also appear as factors of impediment to LP in surveys conducted by Saurin et al. (2010), Bakås et al. (2011) and Moeuf et al. (2016). Shows that the emergence of difficulties is common.

The change in thinking and attitudes of employees and general management in a lean culture is essential, so it's normal the emergence of opposing forces (resistance). When the LP is implemented it needs to be tailored to the specific needs of the company and clients' requirements. Already the understanding of the principles, concept and tools to be implemented must be in the priorities for employee training. Without this and the involvement of greater leadership (general manager) the LP improvement initiative can be perceived by employees as a way to get rid of the workforce, increasing productivity. At this point, the importance of the firm presence of the highest leadership of the company at all times of the implementation is fundamental to ensure the organizational change required to the synergy with the principles of the LP - ensuring long-term guidelines and the availability of expertise to establish and maintain practices and tools.

However, the presence of the general direction is not the only ingredient to ensure the successful implementation of LP. Implement LP requires a change of work organization and systematization. The technical skill (Jones \& Womack, 2004) is also crucial. In other words, the methodology of implementation is also essential for any LP approach.

Therefore, these difficulties highlight the lack of a methodology for aligning the LP concept of educational form in the daily lives of employees and also implement their tools properly and appropriately in SMEs. In this way, could avoid the resistances and, at the same time, turn employees into LP philosophy spanners agents.

Attitudes of resistance from employees of production.

Difficulty in understanding some LP tools..

Lack of knowledge of LP principles.

Lack of commumication.

Difficulty in quantifying the benefits.
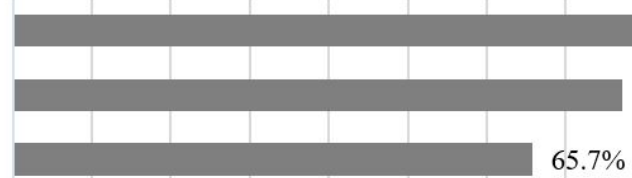
$65.7 \%$

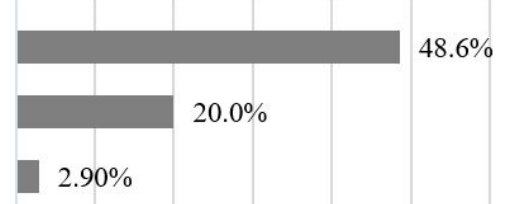

$0.00 \% \quad 10.00 \% 20.00 \% 30.00 \% \quad 40.00 \% 50.00 \% \quad 60.00 \% 70.00 \% 80.00 \% 90.00 \%$

Figure 8. Difficulties encountered to implement LP. 


\subsection{Benefits gained from LP}

The benefits can be many on the implementation of the LP, when this is made correctly and properly in company. Results obtained with this issue showed strong predominance of two options available to the participants in the questionnaire (Figure 9):

1. Cost reduction (85.7\%);

2. Stock reduction $(48.6 \%)$.

The reason and intention the LP is to reduce costs through the reduction of waste. The results presented reflect the practice of the control of the amount of material required for the production (Just-In-Time) which is also seen as a benefit (second benefit chosen with $48.6 \%$ ). Other benefits seem to be well down the scale and may here ask if participants know or quantify such benefits.

Somehow, the thinking "lean" is present in SMEs. This is justified by the understanding of most (84.8\%) of the participants that the LP is a set of tools and techniques to improve operations (Figure 10). However, LP is not yet seen as a different thinking and a "way of life" and without this vision, companies do not give the full potential of this new paradigm. As referred by Godinho et al. (2016), many times, LP is implemented in a fragmented way, without a holistic approach, not achieving greater operational performance.

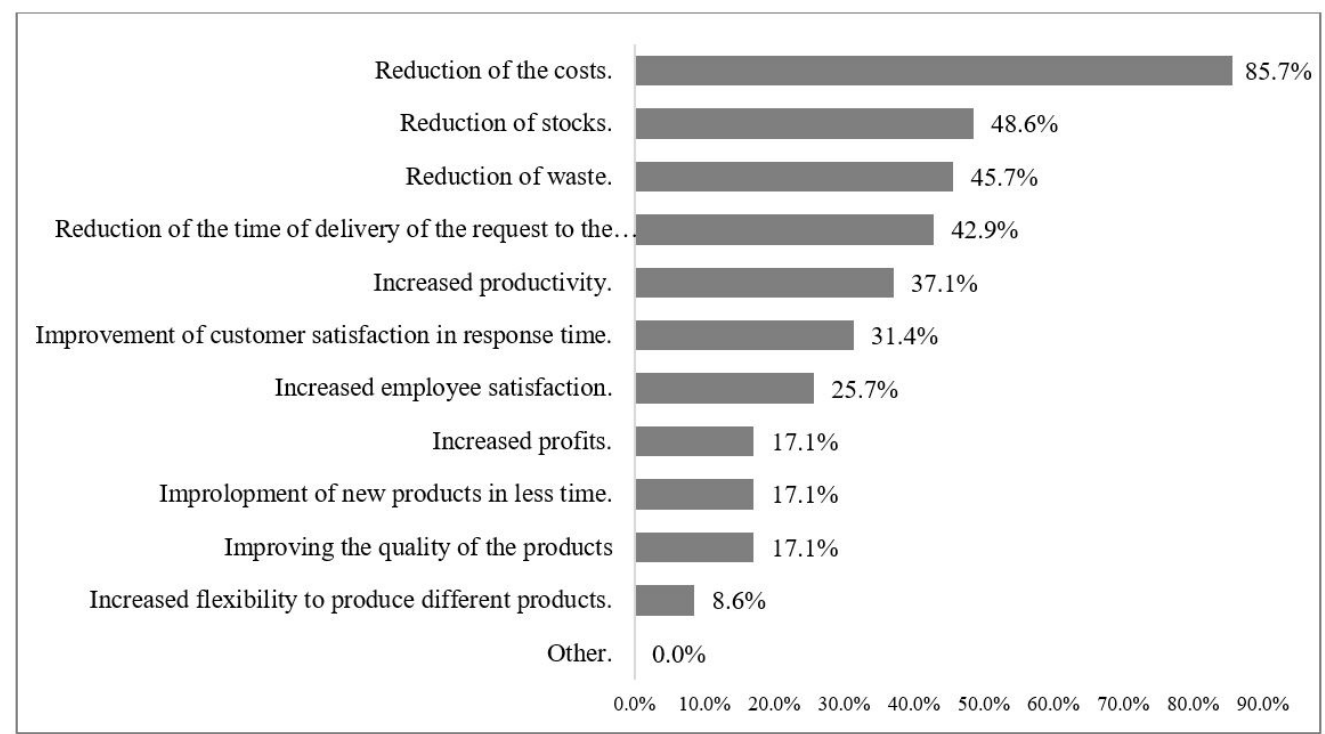

Figure 9. Benefits obtained with the implementation of LP.

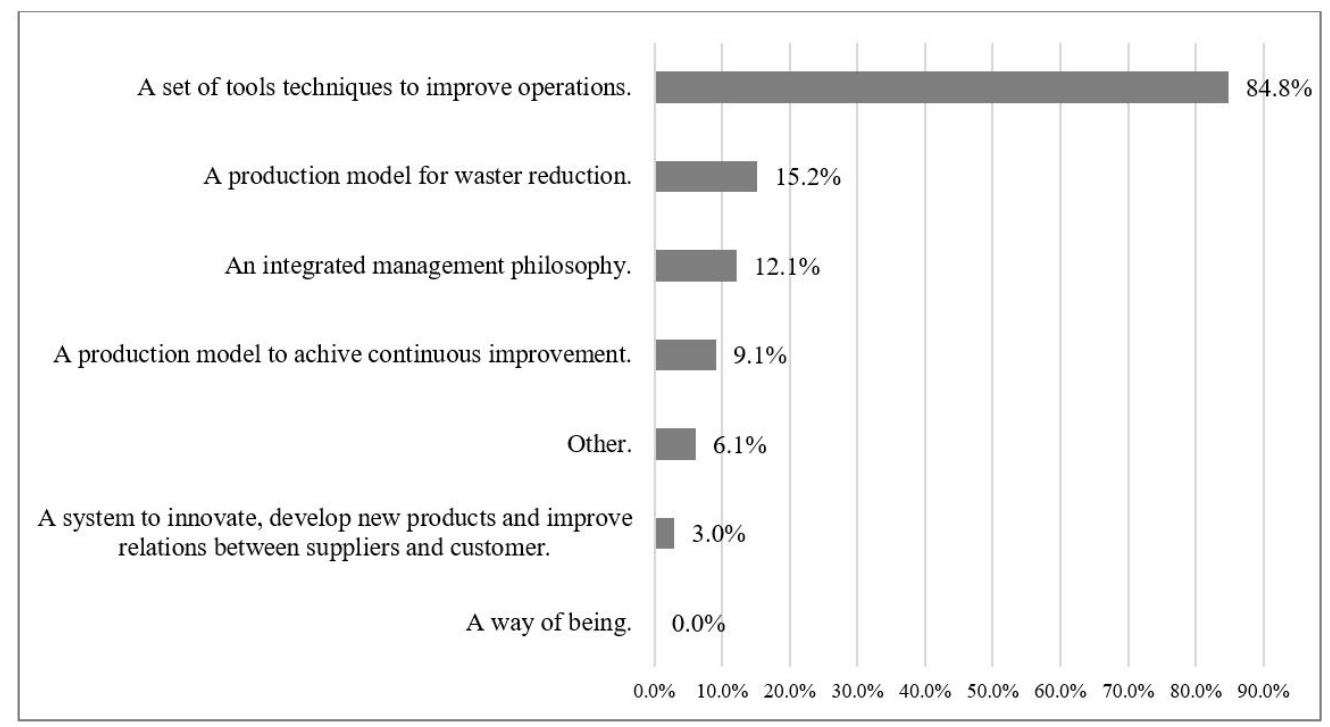

Figure 10. Current understanding of company on LP. 


\section{Conclusions}

This paper presents the results obtained through an exploratory research that aimed to find if LP is being implemented in SMEs. The survey generated responses representatives of 75 SMEs that are headquartered within the ZFM, in the State of Amazonas - the northern region of Brazil. These companies transform raw materials into a final or intermediate product for other manufacturing industry and have already implemented somehow LP tools and techniques.

It stands out the need to investigate on the knowledge that leaders and led have on LP. This study demonstrates that the majority of participants has some knowledge of LP techniques and practices. This can be due to the background in production engineering (64\%) and due to the positions, they occupy in their companies. However, there are signs that this investigation is necessary:

- Low knowledge on some Lean Tools (example: production in small batches and poka-yokes);

- Adoption of measures such as reducing product prices and palliative situations (keeping finished stock thinking that customers can order more, producing in excess since machines can fail or because suppliers are not reliable). These are actions that can generate waste as stock maintenance costs, unnecessary transport, unnecessary movement, loss and obsolescence of products;

- Evidence of implementations of the LP with hopeful connotations (to get quickly the same results reported by other companies);

- Over-hiring of consultancies (91.2\%) for implementation of the LP, which somehow inhibits the knowledge of actual results (integrated tools and training of team members);

- Exposure of lack of understanding of Lean principles and tools, as well as resistance imposed by Staff;

- To disseminate the potential of implementing LP as a paradigm that requires a cultural transformation; and

- To help companies at quantifying the benefits of LP, mainly, the intangible benefits (for example the motivation of employees for continuous improvement).

These factors can also be justified by the large number of instruments (manuals or practical guides) serving as support to implement LP, which is good for understanding Lean philosophy, though not contributing for the knowledge of results regarding the implementation of LP.
When implementing LP, it is common the emergence of difficulties. It is therefore important a correct and proper implementation based on the needs of SMEs. The question is how to implement practices and tools that may be understood as causing the dismissal of an employee, with the reduction of costs (for example, think of LP as an exercise "cost-cutting"). It is important to deepen the knowledge on how to correctly assimilate LP concepts by employees. Thus, avoiding this kind of misunderstanding.

The results obtained and presented in this article showed that the issue deserves further study. This is supported by several findings: limited LP implementation in SMEs; lack of a correct introduction of the LP concepts and its tools; palliative practices (momentary relief) and; hopeful implementations and barriers to LP. There is an opportunity for the development of a methodology contributing for a better implementation of LP in that type of organizations.

As so, these results of this study will contribute to identify needs and opportunities to find a method that could in the future help the implementation of LP correctly and appropriately in SMEs. It can also be relevant as a source or a basis for entering into research problems that have not yet been investigated.

Other relevant need identified in the study concerns procedures and situations. Markets require quick actions to face up competition and also that fundamental measures and strategies are correct, otherwise, the results may not be as expected. In this context, studies about these measures and strategies adopted are also important. Although some methods and strategies may be, in principle, associated with factors such as region, weather and logistical difficulties of the company.

The instrument used in this study, the questionnaire, can also be considered as a tool for use in future research regarding the implementation of LP. This tool can go through further improvements to retain more information. Nevertheless, this constitutes a limitation of this study. This proposal should be a joint initiative of educational institutions linked to industry and to the dissemination of the Lean philosophy.

As future work, we plan to develop tools able to contribute for a better understanding and implementation of LP in SMEs making LP concepts easier to understand. This requires the development of a new methodology to align the LP concept, especially with the knowledge, skill, attitude of employees and also to support the correct implementation of tools (practice) adjusted to the needs of SMEs.

\section{References}

Achanga, P., Shehab, E., Roy, R., \& Nelder, G. (2006). Critical success factors for lean implementation within SMEs. Journal of Manufacturing Technology Management, 17(4), 460-471. http://dx.doi.org/10.1108/17410380610662889. 
Alves, A. C., Kahlen, F., Flumerfelt, S., \& Siriban-Manalang, A.-B. (2014). Lean production multidisciplinary: from operations to education. In Proceedings of 7 th International Conference on Production Research Americas. Lima: Universidad Privada Norbert Wiener. http://doi.org/10.13140/2.1.1524.0005.

Alves, A. C., Sousa, R. M., Dinis-Carvalho, J., \& Moreira, F. (2015). Production systems redesign in a lean context: a matter of sustainability. FME Transactions, 43(4), 344-352. http://dx.doi.org/10.5937/fmet1504344A.

Antosz, K., \& Stadnicka, D. (2017). Lean philosophy implementation in SMEs: study results. Procedia Engineering, 182, 25-32. http://dx.doi.org/10.1016/j. proeng.2017.03.107.

Arlbjørn, J. S., \& Freytag, P. V. (2013). Evidence of lean: a review of international peer-reviewed journal articles. European Business Review, 25(2), 174-205. http:// dx.doi.org/10.1108/09555341311302675.

Bakås, O., Govaert, T., \& Van Landeghem, H. (2011). Challenges and success factors for implementation of lean manufacturing in Europeans SMEs. In Proceedings of MITIP 2011. Ghent: Ghent University. Retrieved in 20147, October 10, from https:// biblio.ugent.be/ publication/1929995

Banco Nacional de Desenvolvimento Econômico e Social - BNDES. (2015). Apoio às micro, pequenas e médias empresas (Vol. 22). Brasília.

Bhamu, J., \& Sangwan, K. S. (2014). Lean Manufacturing: literature review and research issues. International Journal of Operations \& Production Management, 34(7), 876940. http://dx.doi.org/10.1108/IJOPM-08-2012-0315.

Bodek, N. (2002). Lean manufacturing. Manufacturing Engineering, 129(3), 17-18.

Bozdogan, K., Milauskas, R., Mize, J., Nightingale, D., Taneja, A., \& Tonaszuck, D. (2000). Transitioning to a lean enterprise: a guide for leaders (Vol. 1). Massachusetts: Massachusetts Institute of Technology.

Buehlmann, U., \& Fricke, C. F. (2016). Benefits of Lean transformation efforts in small- and medium-sized enterprises. Production \& Manufacturing Research, 4(1), 114-132. http://dx.doi.org/10.1080/21693277.2 016.1212679 .

Cowger, G. (2016). Half measures gets less than half results. Mechanical Engineering The Magazine of ASME, 138(1), 30-35.

Dorota Rymaszewska, A. (2014). The challenges of lean manufacturing implementation in SMEs. Benchmarking, 21(6), 987-1002. http://dx.doi.org/10.1108/BIJ-102012-0065.

Eiriz, V. (2001). Proposta de tipologia sobre alianças estratégicas. Revista de Administração Contemporânea, 5(2), 65-90. http://dx.doi.org/10.1590/S1415-65552001000200004.

European Commission. (2008). Putting small businesses first. Brussels. http://doi.org/10.2769/49755.
Godinho, M., Fo., Ganga, G. M. D., \& Gunasekaran, A. (2016). Lean manufacturing in Brazilian small and medium enterprises: implementation and effect on performance. International Journal of Production Research, 54(24), 7523-7545. http://dx.doi.org/10.10 80/00207543.2016.1201606.

Google Drive. (2017). Retrieved in 20147, October 10, from https://drive.google.com/drive

Hines, P., Holweg, M., \& Rich, N. (2004). Learning to evolve: a review of contemporary lean thinking. International Journal of Operations \& Production Management, 24(10), 994-1011. http://dx.doi.org/10.1108/01443570410558049.

Hu, Q., Mason, R., Williams, S. J., \& Found, P. (2015). Lean implementation within SMEs: a literature review. Journal of Manufacturing Technology Management, 26(7), 980-1012. http://dx.doi.org/10.1108/JMTM02-2014-0013.

Jadhav, J. R., Mantha, S. S., \& Rane, S. B. (2014). Exploring barriers in lean implementation. International Journal of Lean Six Sigma, 5(2), 122-148. http://dx.doi.org/10.1108/ IJLSS-12-2012-0014.

Jasti, N. V. K., \& Kodali, R. (2014). Lean production: literature review and trends. International Journal of Production Research, 53, 1-19. http://dx.doi.org/10.1 080/00207543.2014.937508.

Jones, D. T., \& Womack, J. P. (2004). A mentalidade enxuta nas empresas: elimine o desperdício e crie riqueza (6. ed.). Rio de Janeiro: Campus.

Krafcik, J. F. (1988). Triumph of the lean production system. Sloan Management Review, 30(1), 41-52.

Liker, J. K. (2004). The Toyota way: 14 management principles from the world's greatest manufacturer. New York: McGraw-Hill.

Liker, J. K., \& Meier, D. (2007). O modelo Toyota: manual de aplicação. Um guia prático para a Implementação dos 4Ps da Toyota. Porto Alegre: Bookman.

Maia, L. C., Alves, A. C., \& Leão, C. P. (2016). Lean Production awareness and implementation in Portuguese Textile and Clothing companies. In Proceedings of the Regional Helix 2016, International Conference on Triple Helix Dynamics; Topic: 9. Industry-Academia Interactions and Sustainability. Castelo Branco, Portugal: Springer International Publishing. https:// doi.org/10.1007/978-3-030-13515-7_11.

Marodin, G. A., Saurin, T. A., \& ten Caten, C. S. (2015). Identificação e classificação de riscos na implantação da produção enxuta. Production, 25(4), 911-925. http:// dx.doi.org/10.1590/0103-6513.033011.

Moeuf, A., Tamayo, S., Lamouri, S., Pellerin, R., \& Lelievre, A. (2016). Strengths and weaknesses of small and medium sized enterprises regarding the implementation of lean manufacturing. IFAC-PapersOnLine, 49(12), 71-76. http://dx.doi.org/10.1016/j.ifacol.2016.07.552. 
Monden, Y. (1993). Toyota production system. Atlanta: Springer US. http://dx.doi.org/10.1007/978-1-4615-9714-8.

Moreira, D. A. (2012). Administração da produção e operações (2. ed. rev.). São Paulo: Cengage Learning.

Murman, E., Allen, T., Bozdogan, K., Cutcher-Gershenfeld, J., McManus, H., Nightingale, D., Rebentisch, E., Shields, T., Stahl, F., Walton, M., Warmkessel, J., Weiss, S., \& Widnall, S. (2002). Lean Enterprise value. London: Palgrave Macmillan. http://dx.doi.org/10.1057/9781403907509.

Ohno, T. (1988). Toyota production system: beyond largescale production (3rd ed.). New York: Productivity Press.

Organizacion Internacional del Trabajo. (2015). Panorama Laboral Temático: pequeñas empresas, grandes brechas: empleo y condiciones de trabajo en las MYPE de América Latina y el Caribe (Vol. 1). Geneva: Oficina Regional para América y el Cariber.

Panizzolo, R., Garengo, P., Sharma, M. K., \& Gore, A. (2012). Lean manufacturing in developing countries: evidence from Indian SMEs. Production Planning \& Control: The Management of Operations, 23(10-11), 769-788. http:// dx.doi.org/10.1080/09537287.2011.642155.

Papadopoulou, T. C., \& Özbayrak, M. (2005). Leanness: experiences from the journey to date. Journal of Manufacturing Technology Management, 16(7), 784807. http://dx.doi.org/10.1108/17410380510626196.

Pingyu, Y., \& Yu, Y. (2010). The barriers to SMEs' implementation of lean production and countermeasures: based on SMS in Wenzhou. International Journal of Innovation, Management and Technology, 1(2), 220-225.

Saurin, T. A., \& Ferreira, C. F. (2008). Diretrizes para avaliação dos impactos da produção enxuta sobre as condições de trabalho. Produção, 18(3), 508-522. http://dx.doi.org/10.1590/S0103-65132008000300008.

Saurin, T. A., Ribeiro, J. L. D., \& Marodin, G. A. (2010). Identificação de oportunidades de pesquisa a partir de um levantamento da implantação da produção enxuta em empresas do Brasil e do exterior. Gestão \& Produção, 17(4), 829-841. http://dx.doi.org/10.1590/ S0104-530X2010000400015.

Serviço Brasileiro de Apoio às Micro e Pequenas Empresas - SEBRAE. (2014). A evolução das microempresas e empresas de pequeno porte 2009 a 2012. Brasília.
Serviço Brasileiro de Apoio às Micro e Pequenas Empresas - SEBRAE. (2015). Brasília. Retrieved in 2016, May 10, from www.sebrae.com.br

Shah, R., \& Ward, P. T. (2003). Lean manufacturing: context, practice bundles, and performance. Journal of Operations Management, 21(2), 129-149. http://dx.doi. org/10.1016/S0272-6963(02)00108-0.

Small Business Administration - SBA. (2017). Washington. Retrieved in 2017, January 10, from www.sba.gov/

Smart, P. A., Maull, R. S., Childe, S. J., \& Radnor, Z. J. (2004). Capitalizing on thematic initiatives: a framework for process-based change in SMEs. Production Planning and Control, 15(1), 2-12. http://dx.doi.org/10.1080/09 537280310001649363.

Stone, K. B. (2012). Four decades of lean: a systematic literature review. International Journal of Lean Six Sigma, 3(2), 112-132. http://dx.doi.org/10.1108/20401461211243702.

Superintendência da Zona Franca de Manaus - SUFRAMA. (2016). Nossos valores, nossa gente. Manaus.

Van Goubergen, D., Van Landeghem, H., Van Aken, E., \& Letens, G. (2003). Using value stream mapping to redesign engineering project work. In Proceedings of the IIE Annual Conference (pp. 1-6). Norcross: Institute for Industrial Engineers.

White, R. E., Pearson, J. N., \& Wilson, J. R. (1999). JIT manufacturing: a survey of implementations in small and large U.S. manufacturers. Management Science, 45(1), 1-15. http://dx.doi.org/10.1287/mnsc.45.1.1.

Womack, J. P., \& Jones, D. T. (1996). Lean thinking by womack and jones. Review: Literature and Arts of the Americas, 5.

Womack, J. P., \& Jones, D. T. (1997). Lean thinking: banish waste and create wealth in your corporation. The Journal of the Operational Research Society, 48(11), 1148-1149. http://dx.doi.org/10.1057/palgrave.jors.2600967.

Womack, J. P., Jones, D. T., \& Roos, D. (1990a). The machine that changed the world: the story of lean production. New York: Rawson Associates.

Womack, J. P., Jones, D. T., \& Roos, D. (1990b). The machine that changed the world. New York: Rawson Associates. 